\title{
МОДЕЛЬНИЙ СТАТУТ ЯК УСТАНОВЧИЙ ДОКУМЕНТ ТА ОСОБЛИВОСТІ ЙОГО ВИКОРИСТАННЯ
}

\section{MODEL STATUTE AS A CONSTITUTIONAL DOCUMENT AND FEATURES OF ITS USE}

\author{
Тепла Мирослава Миронівна \\ асистент кафредри економіки підприємства, \\ Львівський національний університет імені Івана Франка \\ ORCID: https://orcid.org/0000-0002-7339-2194 \\ Myroslava Tepla \\ Ivan Franko National University of Lviv
}

\begin{abstract}
У статті досліджено особливості використання модельного статуту як установчого документа юридичної особи. Розглянуто поняття модельного статуту, переваги та недоліки його застосування. Зазначено перелік документів, необхідних для державної реєстрації переходу юридичної особи на діяльність на підставі модельного статуту, а також переходу з модельного статуту на діяльність на підставі власного установчого документа. Охарактеризовано зміст модельного статуту товариства з обмеженою відповідальністю та можливості формування власної редакції. Висвітлено особливості онлайн-реєстрації товариства з обмеженою відповідальністю на підставі модельного статуту та переходу юридичної особи на діяльність на підставі модельного статуту. Вказано основні нормативно-правові акти, які регламентують використання модельного статуту в Україні.
\end{abstract}

Ключові слова: установчі документи, статут, модельний статут, суб'єкт господарювання, юридична особа, товариство з обмеженою відповідальністю.

В статье исследованы особенности использования модельного устава в качестве учредительного документа юридического лица. Рассмотрены понятие модельного устава, преимущества и недостатки его применения. Указан перечень документов, необходимых для государственной регистрации перехода юридического лица на деятельность на основании модельного устава, а также перехода из модельного устава на деятельность на основании собственного учредительного документа. Охарактеризованы содержание модельного устава общества с ограниченной ответственностью и возможности формирования собственной редакции. Освещены особенности онлайн-регистрации общества с ограниченной ответственностью на основании модельного устава и перехода юридического лица на деятельность на основании модельного устава. Указаны основные нормативно-правовые акты, которые регламентируют использование модельного устава в Украине.

Ключевые слова: учредительные документы, устав, модельный устав, субъект хозяйствования, юридическое лицо, общество с ограниченной ответственностью.

One of the priority tasks in the creation and registration of an enterprise as a legal entity is the development of constituent documents. The current legislation of Ukraine stipulates that an economic entity may be created and act on the basis of a model charter, which after its adoption by the participants becomes a constituent document. Information on whether the legal entity operates on the basis of the model statute is indicated in the application for state registration of the legal entity (except for public formations and authorities) and the Unified State Register. Currently in Ukraine, activities on the basis of the model charter as a constituent document can be carried out only by a business company in the form of a limited liability company. On March 27, 2019, the Cabinet of Ministers of Ukraine approved a new version of the model charter of a limited liability company. The purpose of the article is to study the peculiarities of the creation and conduct of legal entities (limited liability companies) on the basis of the model charter, to determine the advantages and disadvantages of its use as a constituent document. The article examines the peculiarities of using the model charter as a constituent document of a legal entity. The concept of model charter, advantages and disadvantages of its use are considered. The list of documents required for state registration of the transition of a legal entity to an activity on the basis of a model charter, as well as the transition from a model charter to an activity on the basis of its own constituent document is indicated. The content of the model charter of a limited liability company and the possibility of forming its own editorial office are described. 
The peculiarities of online registration of a limited liability company on the basis of the model charter and the transition of a legal entity to activity on the basis of the model charter are highlighted. The main normative legal acts regulating the use of the model charter in Ukraine are indicated. The practical value of the article lies in the study of regulatory and legal support for the activities of enterprises on the basis of the model charter and coverage of current issues of its use as a constituent document.

Keywords: founding documents, charter, model charter, business entity, legal entity, limited liability company.

Постановка проблеми. Розробка установчих документів $€$ одним із першочергових завдань при створенні та реєстрації підприємства як юридичної особи. 3 метою спрощення процесу підготовки документів на проведення державної реєстрації юридичних осіб в Україні Законом України «Про внесення змін до деяких законодавчих актів України щодо запровадження принципу державної реєстрації юридичних осіб на підставі модельного статуту» від 21 квітня 2011 року № 3262-VI [1] запроваджено можливість створення та діяльності юридичної особи на підставі модельного статуту.

16 листопада 2011 року постановою Кабінету Міністрів України № 1182 «Про затвердження модельного статуту товариства 3 обмеженою відповідальністю» [2] було затверджено модельний статут товариства 3 обмеженою відповідальністю. Проте, у зв'язку 3 прийняттям Закону України «Про товариства з обмеженою та додатковою відповідальністю» від 6 лютого 2018 року № 2275-VIII [3], який набув чинності з 17 червня 2018 року, використання цього модельного статуту було обмеженим через неузгодженість із положеннями закону.

27 березня 2019 року була прийнята постанова Кабінету Міністрів України № 367 «Деякі питання дерегуляції господарської діяльності», яка набула чинності від 28 квітня 2019 року [4], зокрема, у частині затвердження нового модельного статуту товариства 3 обмеженою відповідальністю, відповідно до якої товариства 3 обмеженою відповідальністю знову отримали можливість при створенні обрати діяльність на підставі модельного статуту або перейти на таку діяльність, якщо до цього діяли на підставі власного статуту.

Аналіз останніх досліджень і публікацій. Основними нормативно-правовими актами, які регламентують особливості використання модельного статуту як установчого документа, є: Господарський кодекс України [5], Закон України «Про державну реєстрацію юридичних осіб, фрізичних осіб-підприємців та громадських формувань» [6], Закон України «Про внесення змін до деяких законодавчих актів України щодо запровадження принципу державної реєстрації юридичних осіб на підставі модельного статуту» [1], Закон України «Про товариства з обмеженою та додатковою відповідальністю» [3], постанова Кабінету Міністрів України «Деякі питання дерегуляції господарської діяльності» [4] тощо.

Формулювання цілей статті (постановка завдання). Метою статті $€$ дослідження особливостей створення та діяльності юридичних осіб на підставі модельного статуту, визначення переваг та недоліків його використання як установчого документа.

Виклад основного матеріалу дослідження. Відповідно до ч. 4 ст. 56 Господарського кодексу України, суб'єкт господарювання може створюватися та діяти на підставі модельного статуту [5].

Модельний статут - це типовий установчий документ, затверджений Кабінетом Міністрів України, який використовується для створення та провадження діяльності юридичних осіб відповідних організаційно-правових фрорм, містить встановлені законом правила, що регулюють правовий статус, права, обов'язки та відносини, які пов'язані зі створенням, управлінням та провадженням господарської діяльності відповідних юридичних осіб [1].

Метою запровадження модельного статуту в Україні стало спрощення процедури проведення державної реєстрації юридичних осіб, започаткування та ведення підприємницької діяльності, покращення інвестиційного клімату та умов ведення бізнесу в країні.

Серед ключових переваг використання модельного статуту як установчого документа варто відзначити те, що його не потрібно подавати для державної реєстрації створення юридичної особи (згідно ч. 1 п. 5 ст. 17 Закону України № 755-IV для державної реєстрації створення юридичної особи установчий документ юридичної особи подається у разі створення юридичної особи на підставі власного установчого документа), розробляти, нотаріально засвідчувати справжність підписів засновників, витрачати час і кошти на розробку тощо. Разом з тим зазначимо, що діяльність суб'єктів господарювання на підставі модельного статуту має й низку обмежень. Так, зокрема, самостійно внести зміни у 
положення модельного статуту є неможливо, а якщо будь-які зміни до модельного статуту вносить Кабінет Міністрів України, то такі зміни підлягають обов'язковому виконанню. Переваги та недоліки здійснення діяльності юридичних осіб на підставі модельного статуту представлено у табл. 1.

Слід відзначити, що чинним законодавством України передбачено можливість переходу юридичної особи на діяльність на підставі модельного статуту, а також переходу юридичної особи з модельного статуту на діяльність на підставі власного установчого документа. Перелік документів, необхідних для здійснення такого переходу, визначений ст. 17 Закону України № 755-IV ч. 7 і ч. 8 відповідно (рис. 1).

Зазначимо, що на даний час в Україні діяльність на підставі модельного статуту як установчого документа може здійснювати лише господарське товариство у формі товариства з обмеженою відповідальністю. Вперше модельний статут для товариства з обмеженою відповідальністю був затверджений постановою Кабінету Міністрів України «Про затвердження модельного статуту товариства з обмеженою відповідальністю» від 16 листопада 2011 р. № 1182. 27 березня 2019 року постановою Кабінету Міністрів України № 367 «Деякі питання дерегуляції господарської діяльності» було затверджено нову редакцію модельного статуту товариства 3 обмеженою відповідальністю, яка набула чинності 28 квітня 2019 року.

Модельний статут товариства 3 обмеженою відповідальністю містить загальні положення; відомості про статутний капітал та вклади учасників товариства; порядок вступу до товариства та виходу з нього; дивіденди; органи управління товариством, їх компетенцію, порядок прийняття ними рішень; значні правочини та правочини, щодо вчинення яких $€$ заінтересованість; прикінцеві положення [4].

Ключовою особливістю нової редакції модельного статуту товариства з обмеженою відповідальністю стало те, що чимало його положень $€$ багатоваріантними, зокрема ті, що стосуються строків, необхідної кількості голосів для прийняття рішень тощо. Це дає можливість засновникам (учасникам) товариства при поданні документів для проведення державної реєстрації створення товариства з обмеженою відповідальністю на підставі модельного статуту, або переходу на діяльність на підставі модельного статуту, самостійно

\section{Переваги та недоліки провадження діяльності юридичних осіб на підставі модельного статуту як установчого документа}

Таблиця 1

\begin{tabular}{|c|c|}
\hline 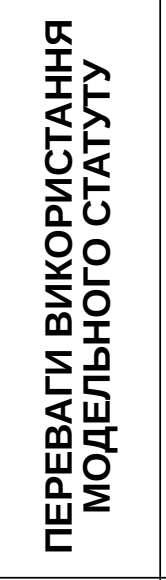 & $\begin{array}{l}\text { - модельний статут не потрібно подавати для державної реєстрації створення } \\
\text { юридичної особи; } \\
\text { - не потрібно нотаріально засвідчувати справжність підписів засновників на } \\
\text { модельному статуті; } \\
\text { - не потрібно витрачати час та кошти на складання установчого документа; } \\
\text { - у випадку необхідності внесення змін до відомостей про юридичну особу } \\
\text { (наприклад, зміни адреси, складу учасників, розміру статутного капіталу, видів } \\
\text { діяльності, найменування тощо) не потрібно затверджувати нову редакцію статуту } \\
\text { та подавати її державному реєстратору; } \\
\text { - не потрібно нотаріально засвідчувати копії статуту та відновлювати статут, якщо } \\
\text { він був втрачений; } \\
\text { - не потрібно враховувати всі вимоги законодавства до змісту установчих } \\
\text { документів; } \\
\text { - модельний статут неможливо підробити, що гарантує захист прав та інтересів } \\
\text { юридичної особи від неправомірних дій інших осіб тощо. }\end{array}$ \\
\hline 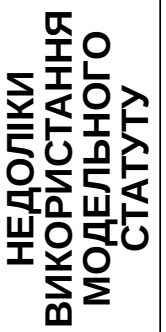 & $\begin{array}{l}\text { - неможливо самостійно внести зміни у положення модельного статуту; } \\
\text { - якщо Кабінет Міністрів України вносить зміни до положень модельного статуту, } \\
\text { то такі зміни стосуються всіх товариств, які діють на його підставі, та підлягають } \\
\text { беззаперечному їх виконанню; } \\
\text { - неможливо зазначити у статуті необхідні учасникам товариства положення, } \\
\text { наприклад, щодо обмеження повноважень директора, порядок прийняття рішень } \\
\text { органами управління товариства, визначення кворуму загальних зборів та ін. }\end{array}$ \\
\hline
\end{tabular}




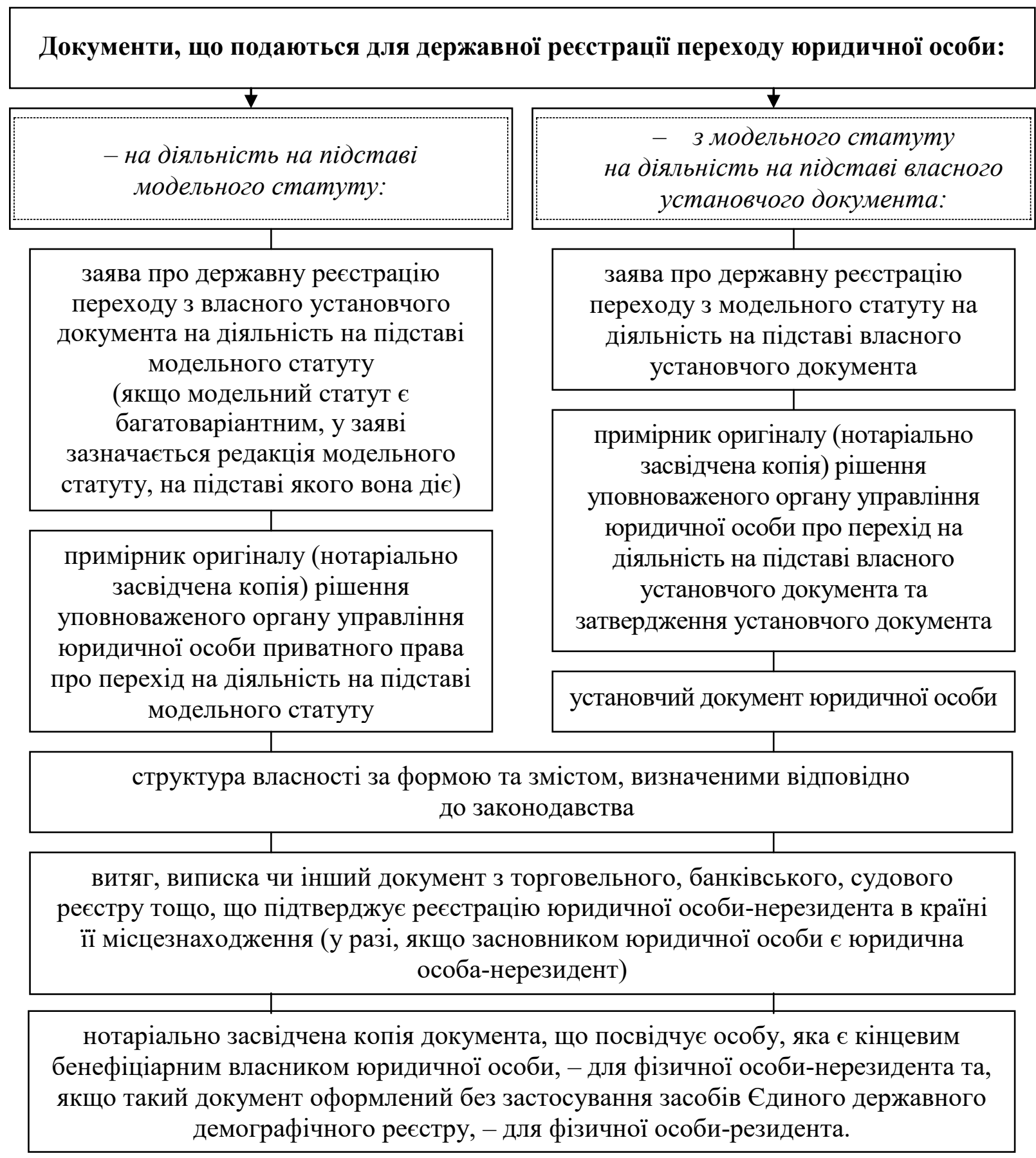

Рис. 1. Перелік документів, які подаються для державної реєстрації переходу юридичної особи на діяльність на підставі власного установчого документа або модельного статуту Джерело: складено на основі [6]

сорормувати найбільш прийнятну для себе редакцію модельного статуту або ж обрати варіант «за замовчуванням», який фрормується з положень, рекомендованих Кабінетом Міністрів України (у статуті ці пункти позначені «*»). Проте варто зазначити, що така можливість вибору є лише при поданні документів у електронній фрормі, якщо документи подаються у паперовій фрормі, - вважається, що обрано варіант «за замовчуванням» [4]. Крім того, відповідно до ч. 11 ст. 11 Закону України «Про товариства з обмеженою та додатковою відповідальністю» товариство має право у будь-який час змінити редакцію модельного статуту, на підставі якого воно діє, вибравши інші положення із запропонованих [3].

Можливість зареєструвати товариство з обмеженою відповідальністю на підставі 
модельного статуту в онлайн-режимі в Україні з'явилася 9 липня 2019 року на порталі «Онлайн-будинок юстиції» та веб-порталі Кабінету Міністрів України у розділі «Електронні послуги» [8]. На даний час онлайнреєстрація товариства з обмеженою відповідальністю на підставі модельного статуту доступна на порталі «Дія» (https://diia.gov. ua/). Дана електронна послуга $€$ безкоштовною та загалом передбачає можливість: формування власної редакції модельного статуту шляхом вибору відповідних пунктів або використання редакції «за замовчуванням»; переходу юридичних осіб на діяльність на підставі модельного статуту; подання заяви на застосування спрощеної системи оподаткування; реєстрації платником податку на додану вартість. Для того потрібно:

1. Зареєструватися або авторизуватися на порталі в кабінеті громадянина на сайті https://diia.gov.ua.

2. Мати квалісрікований електронний підпис, оскільки всі документи мають бути підписані за допомогою електронного підпису.

3. Заповнити онлайн-фрорму на отримання послуги та вибрати необхідні пункти модельного статуту або редакцію статуту «за замовчуванням».

Після того автоматично фрормуються заява, статут, протокол зборів засновників (або рішення/протокол про перехід на діяльність на модельному статуті) та надсилаються до державного реєстратора. Реєстрація здійснюється протягом 1 робочого дня, крім вихідних та святкових днів. Повідомлення про реєстрацію чи відмову надходять у кабінет громадянина та електронну пошту. Запис про реєстрацію товариства з'являється у Єдиному державному реєстрі $[9 ; 10]$.

Наприкінці зазначимо, що положення модельного статуту мають загальний характер, стосуються діяльності всіх товариств з обмеженою відповідальністю, тому, якщо товариство створюється та діє на підставі модельного статуту, у рішенні засновників (учасників) товариства необхідно зазначити предмет діяльності, склад засновників (учасників), розмір статутного капіталу, розмір часток у статутному капіталі кожного 3 учасників, спосіб внесення ними вкладів (у грошовій та/або негрошовій формі) [4]. Відповідно до ч. 10 ст. 11 Закону України «Про товариства 3 обмеженою та додатковою відповідальністю», рішення засновників про створення товариства на підставі модельного статуту та рішення учасників про провадження діяльності на підставі модельного статуту підписуються усіма засновниками (учасниками), а рішення учасників про перехід товариства 3 модельного статуту на діяльність на підставі статуту та рішення учасників про зміну редакції модельного статуту, на підставі якого діє товариство, підписуються учасниками, які голосували за відповідне рішення. Справжність підписів засновників (учасників) засвідчується нотаріально, крім рішень, створених на порталі електронних сервісів та підписаних з використанням кваліфрікованого електронного підпису [3].

Висновки. Підсумовуючи, можна зробити наступні висновки:

- розробка установчих документів є одним із першочергових завдань при створенні та державній реєстрації підприємства як юридичної особи;

- юридична особа може створюватися та діяти на підставі модельного статуту, який $є$ типовим установчим документом, затвердженим Кабінетом Міністрів України, та після прийняття його учасниками стає ії установчим документом;

- юридична особа може обрати модельний статут при державній реєстрації, або перейти на нього у будь-який момент після створення, водночас юридична особа, що діє на основі модельного статуту, у будь-який час може перейти на власний статут або змінити його редакцію;

- модельний статут як установчий документ на даний час в Україні затверджений Кабінетом Міністрів України лише для товариства $з$ обмеженою відповідальністю;

- оскільки модельний статут товариства 3 обмеженою відповідальністю $є$ типовим установчим документом і не містить відомостей для ідентифрікації конкретного товариства (зокрема, про найменування, юридичну адресу, склад учасників тощо), таку інформацію слід зазначати у рішенні засновників (учасників) товариства;

- деякі положення модельного статуту товариства 3 обмеженою відповідальністю $€$ багатоваріантними, що дає можливість засновникам (учасникам) самостійно сорормувати найбільш прийнятну для себе редакцію модельного статуту, однак така можливість $€$ лише при поданні документів у електронній формі; при поданні документів у паперовій формі обирається варіант «за замовчуванням». 


\section{СПИСОК ВИКОРИСТАНИХ ДЖЕРЕЛ:}

1. Про внесення змін до деяких законодавчих актів України щодо запровадження принципу державної реєстрації юридичних осіб на підставі модельного статуту : Закон України від 21 квітня 2011 року № 3262-VI. URL: https://zakon.rada.gov.ua/laws/show/3262-17

2. Про затвердження модельного статуту товариства з обмеженою відповідальністю : постанова Кабінету Міністрів України від 16 листопада 2011 року № 1182. URL: https://zakon.rada.gov.ua/laws/show/1182-2011$\% \mathrm{D} 0 \% \mathrm{BF}$

3. Про товариства з обмеженою та додатковою відповідальністю : Закон України від 6 лютого 2018 року № 2275-VIII (із змінами). URL: https://zakon.rada.gov.ua/laws/show/2275-19

4. Деякі питання дерегуляції господарської діяльності : постанова Кабінету Міністрів України № 367 від 27 березня 2019 року. URL: https://zakon.rada.gov.ua/laws/show/367-2019-\%D0\%BF

5. Господарський кодекс України від 16 січня 2003 року № 436-IV (із змінами). URL: http://zakon3.rada.gov.ua/ laws/show/436-15

6. Про державну реєстрацію юридичних осіб, фрізичних осіб-підприємців та громадських фрормувань : Закон України від 15 травня 2003 року № 755-IV (із змінами). URL: http://zakon3.rada.gov.ua/laws/show/755-15

7. Петутіна Ю. Новий модельний статут. 2019. URL: http://yurradnik.com.ua/stati/noviy-modelniy-statut/

8. Відтепер зареєструвати ТОВ можна онлайн. 2019. URL: https://minjust.gov.ua/news/ministry/vidteperzareestruvati-tov-mojna-onlayn

9. Реєстрація TOB на підставі модельного статуту (н. д.). URL: https://diia.gov.ua/services/reyestraciya-tovna-pidstavi-modelnogo-statutu

10.Перехід юридичної особи на діяльність на підставі модельного статуту (н. д.). URL: https://diia.gov.ua/ services/perehid-tov-na-modelnij-statut

\section{REFERENCES:}

1. Pro vnesennia zmin do deiakykh zakonodavchykh aktiv Ukrainy schodo zaprovadzhennia pryntsypu derzhavnoi reiestratsii iurydychnykh osib na pidstavi model'noho statutu: Zakon Ukrainy vid 21 kvitnia 2011 roku № 3262-VI. Retrieved from: https://zakon.rada.gov.ua/lavs/shov/3262-17

2. Pro zatverdzhennia model'noho statutu tovarystva z obmezhenoiu vidpovidal'nistiu: postanova Kabinetu Ministriv Ukrainy vid 16 lystopada 2011 r. № 1182. Retrieved from: https://zakon.rada.gov.ua/lavs/shov/1182-2011$\% \mathrm{D} 0 \% \mathrm{BF}$

3. Pro tovarystva z obmezhenoiu ta dodatkovoiu vidpovidal'nistiu: Zakon Ukrainy vid 6 liutoho 2018 roku № 2275-VIII (iz zminamy). Retrieved from: https://zakon.rada.gov.ua/lavs/shov/2275-19

4. Deiaki pytannia derehuliatsii hospodars'koi diial'nosti: postanova Kabinetu Ministriv Ukrainy № 367 vid 27 bereznia 2019 roku. Retrieved from: https://zakon.rada.gov.ua/lavs/shov/367-2019-\%D0\%BF

5. Hospodars'kyj kodeks Ukrainy vid 16 sichnja 2003 roku № 436-IV (iz zminamy). Retrieved from: http://zakon3.rada.gov.ua/lavs/shov/436-15

6. Pro derzhavnu reiestratsiiu iurydychnykh osib, fizychnykh osib-pidpryiemtsiv ta hromads'kykh formuvan': Zakon Ukrainy vid 15 travnia 2003 roku № 755-IV (iz zminamy). Retrieved from: http://zakon3.rada.gov.ua/lavs/ shov/755-15

7. Petutina, Yu. (2019). Novyj model'nyj statut. Retrieved from: http://iurradnik.tsom.ua/stati/noviy-modelniy-statut/

8. Vidteper zarejestruvaty TOV mozhna onlajn (2019). Retrieved from: https://minjust.gov.ua/news/ministry/ vidteper-zareestruvati-tov-mojna-onlayn

9. Rejestracija TOV na pidstavi modeljnogho statute (n.d). Retrieved from: https://diia.gov.ua/services/ reyestraciya-tov-na-pidstavi-modelnogo-statutu

10.Perekhid jurydychnoji osoby na dijaljnistj na pidstavi modeljnogho statutu (n.d). Retrieved from: https://diia.gov.ua/services/perehid-tov-na-modelnij-statut/ 